\title{
Development of a recombinant Taq DNA polymerase enzyme expressed using a synthetic gene and its comparison with a commercial enzyme
}

\author{
Yuliana $^{\mathrm{a}, \mathrm{b}^{*}}$, Uus Saepuloh ${ }^{\mathrm{b}}$, Suryani ${ }^{\mathrm{a}}$ \\ ${ }^{a}$ Department of Biochemistry, Faculty of Mathematics and Natural Science, IPB University, Jalan Bungur No. 1, Kec. Dramaga, Bogor \\ 16680, Indonesia \\ ${ }^{\circ}$ Primates Research Center (PSSP), IPB University, Jalan Lodaya II, No. 5, Kec. Bogor Tengah, Kota Bogor 16151, Indonesia
}

Received 31st August 2020 / Accepted 19th April 2021

\begin{abstract}
Taq DNA polymerase is a thermostable enzyme widely used for DNA amplification in the PCR technique. It was initially characterized and isolated from thermophilic bacteria, Thermus aquaticus. It was difficult to developed in this enzyme using a native host system. Therefore, the development of the recombinant Taq DNA polymerase expressed using a synthetic gene is important to improve production efficiency. In this study, we developed the in house Taq DNA polymerase recombinant based on a codonoptimized using E. coli expression system. We cloned 2685 bp of the Taq DNA polymerase gene in the pET151/D-TOPO vector. The gene was synthesized and the expression was analyzed with SDS-PAGE technique which indicated with a $100.9 \mathrm{kDa}$ specific target protein. The concentration and activity of this purified enzyme were $5.17 \mathrm{mg} / \mathrm{mL}$ and $4.647 \mathrm{U} / \mu \mathrm{L}$, respectively. The application of this enzyme to the PCR technique showed that this enzyme could amplify the target genes from $200 \mathrm{bp}$ to $3500 \mathrm{bp}$ amplicons with a minimum DNA concentration template $10 \mathrm{ng} / \mu \mathrm{L}$. This assumes that the in house recombinant Taq DNA polymerase based on synthetic genes is successfully expressed, purified, and was functional and comparable to the commercial Taq polymerase.
\end{abstract}

Keywords: Codon-optimized, E. coli BL21, $\mathrm{Ni}^{2+}$-NTA purified system, synthetic Taq DNA polymerase

\section{INTRODUCTION}

Molecular biology is one of the basic scientific disciplines that has an important role in supporting the development of modern biotechnology. One of the techniques that is used in molecular biology is PCR (polymerase chain reaction). PCR is widely applied for DNA sequencing (Ishino and Ishino, 2014), detection of infectious agents, diagnosis of genetic diseases, genetic identification, fingerprinting, production of genetically modified organisms (GMO), genetic modification, and production of recombinant proteins (Niimi et al., 2011).

One of the important reagents that is used in PCR is the thermostable DNA polymerase enzyme, which acts as an enzyme that can extend DNA strands in accordance with its template, DNA, or cDNA (complementary DNA). This enzyme is commercially available in the market, but in Indonesia, the procurement of the enzyme still relies on imports, which causes high prices

*Author for correspondence: Yuliana, Department of Biochemistry, Faculty of Mathematics and Natural Science, IPB University, Jalan Bungur No. 1, Kec. Dramaga, Bogor 16680, Indonesia.

Email -yuliana_180011@apps.ib.ad.id 
and requires a long time to supply. This condition causes the need for domestic research to develop and produce thermostable polymerase enzyme, so that in the future, it can reduce dependence on imported reagents.

Taq DNA polymerase is a thermostable enzyme that was first isolated from thermophilic bacteria, Thermus aquaticus (Chien et al., 1976) and successfully applied in vitro to improve PCR test performance (Mullis and Faloona, 1987; Wang et al., 2004). However, the expression of the enzyme in the native host is very low because these thermophilic bacteria only grow at high temperatures. To overcome this problem, Taq DNA polymerase gene was expressed in Escherichia coli (E. coli) (Engelke et al., 1990). The $E$. coli expression system is able to produce recombinant enzymes commercially, but the methods used in the stages of construction, cloning, and purification are quite difficult to do, so the price of the enzymes produced is expensive.

The development of the Taq DNA polymerase recombinant in this research used a synthetic gene that encoded the Taq DNA polymerase enzyme obtained from GenBank data. The Taq DNA polymerase synthetic gene was constructed, and its codon was optimized as a source of DNA template. Genetic engineering construction of Taq DNA polymerase sequences with codon optimization was designed to avoid the effect of individual codon usage (codon preferences), which would affect the effectiveness of gene expression, considering that the enzyme will be expressed heterologously using the E. coli expression system (Gordeeva et al., 2010). Another advantage of using a synthetic gene is that synthetic gene technology is relatively new and can be designed and modified as needed. In addition, it is also possible to obtain nucleic acid analogues, which cannot be obtained naturally by adding additional nucleotides (Pinheiro et al., 2012).

The purpose of this research is to develop an in house recombinant Taq DNA polymerase enzyme using a synthetic gene in the E. coli expression system. The production of this Taq DNA polymerase recombinant enzyme is expected to reduce dependence on similar products imported, so it will support the advancement of biotechnology in Indonesia.

\section{MATERIALS AND METHODS}

\section{Synthetic gene constructions}

The target gene for synthetic recombinant Taq DNA polymerase enzyme obtained from Genbank data as a reference with access code J04639.1, encodes Thermus aquaticus DNA polymerase (PolI) gene (Lawyer et al., 1989). The gene sequences then were "codon optimized" (GeneArt, Life Technologies). The sequences of optimized codon Taq DNA polymerase were synthesized by GeneArt ${ }^{\circledR}$ Gene Synthetics, Life Technologies (USA) in the form of a doublestranded DNA, which has been inserted into the pET151 / D-TOPO plasmid.

\section{Protein expression}

The protein expression followed the modified procedure from the manufacturer (Invitrogen, USA), as $5 \mu \mathrm{L}(50 \mathrm{ng})$ of the synthetic gene in pET151/D-TOPO was directly transformed in one vial of E. coli BL21 (DE3). The vial containing the transformant was incubated for 30 minutes on ice and continued with heat shock reaction at $42^{\circ} \mathrm{C}$ for 30 seconds. Then, $250 \mu \mathrm{L}$ SOC medium was added and continued with incubation in the incubator shaker with $150 \mathrm{rpm}$ at $37^{\circ} \mathrm{C}$ for 30 minutes. After that, the transformant was inoculated into $10 \mathrm{~mL}$ of $\mathrm{LB}$ medium containing $100 \mu \mathrm{g} / \mathrm{mL}$ ampicillin and was grown at $37^{\circ} \mathrm{C}$ overnight. Then, the inoculum was transferred into $200 \mathrm{~mL} \mathrm{LB}$ medium containing $100 \mu \mathrm{g} / \mathrm{mL}$ ampicillin and was grown for 3 hours at $37^{\circ} \mathrm{C}$. IPTG (Isopropyl- $\beta$-D thiogalactopyranoside) with final concentration of $10 \mathrm{mM}$ was added to the medium and incubated at $37^{\circ} \mathrm{C}$ for 1 until 3 hours with shaking at $150 \mathrm{rpm}$ and collected every hour to obtain the optimum expression. After induction for 3 hours, the cells were harvested by centrifugation at $4000 \mathrm{xg}$ for 20 minutes at $4^{\circ} \mathrm{C}$. The supernatant was removed, and the pellet containing the recombinant protein was resuspended with Bug Buster protein extraction solution (1 gram pellet in $5 \mathrm{~mL}$ solution) (Novagen, USA) and homogenized.The solution was shaken while incubated on ice for 1 hour. After that, the solution was centrifuged at 16000 $\mathrm{xg}$ for 20 minutes at $4^{\circ} \mathrm{C}$, and supernatant as a clear lysate was collected for further protein 
purification process. The collected inoculum and supernatant were analyzed with SDS-PAGE.

\section{Protein purification}

The purification of clear lysate was conducted using the immobilized metal affinity chromatography (IMAC) technique following the modified from Probond (Invitrogen, USA). The column was prepared with $2 \mathrm{~mL}$ of the resin containing $\mathrm{Ni}^{2+}$-NTA particle into a filtration column and the resin allowed to settle completely by gravity (5-10 minutes). After that, about $6 \mathrm{~mL}$ native binding buffer at final pH $8.0(250 \mathrm{mM}$ $\mathrm{NaH}_{2} \mathrm{PO}_{4}, 2.5 \mathrm{M} \mathrm{NaCl}, 10 \mathrm{mM}$ Imidazole, $\mathrm{pH}$ 6.0) were added into the column, and the resin was resuspended by alternately inverting and gently tapping then allowing the resin to settle completely by gravity, and then the supernatant was removed. About $8 \mathrm{~mL}$ clear lysates were added into the filtration column and incubated on ice for one hour with shaking, and flow-through was collected. The column was then washed with washing buffer at final $\mathrm{pH} \quad 8.0 \quad(250 \mathrm{mM}$ $\mathrm{NaH}_{2} \mathrm{PO}_{4}, 2.5 \mathrm{M} \mathrm{NaCl}, 20 \mathrm{mM}$ Imidazole, $\mathrm{pH}$ 6.0) and repeated four times. The resin was settled by gravity, and the supernatant containing unbound proteins was removed. Finally, the histidine-tagged proteins were eluted with $8 \mathrm{~mL}$ native elution buffer at final pH $8.0(250 \mathrm{mM}$ $\mathrm{NaH}_{2} \mathrm{PO}_{4}, 2.5 \mathrm{M} \mathrm{NaCl}, 250 \mathrm{mM}$ Imidazole, $\mathrm{pH}$ 6.0), and supernatant was collected for dialysis processing.

The dialysis process was performed using 14000 MWCO (molecular weight cut off) cellophane membrane against $50 \mathrm{mM}$ Tris- $\mathrm{HCl}$ $\mathrm{pH} 8.5$ for one night. The enzyme was concentrated using PEG (polyethylene glycol) 6000 until obtaining one-tenth of the initial volume. The protein concentration was quantitatively measured using nanodrop C1000 (Thermofisher, USA) at $280 \mathrm{~nm}$ wavelength. The analysis of Taq DNA polymerase enzyme recombinant expression was performed using SDS-PAGE technique.

\section{Polymerase activity assay}

The enzyme activity assay was performed using a modified EvaEZ Fluorometric Polymerase Activity Assay kit (Biotium, US), following the procedure of Suppan et al. (2015) as the reaction mixture contained $10 \mu \mathrm{L} 2 \mathrm{xEvaEZ}$ fluorometric polymerase activity mix, $9 \mu \mathrm{L}$ sterile $\mathrm{dH}_{2} \mathrm{O}$, and 1 $\mu \mathrm{L}$ polymerase enzyme with unknown concentration. The reaction was run on the realtime PCR (iQ5, Biorad) at the isothermal temperature of $72^{\circ} \mathrm{C}$ for 45 minutes and the RFU (relative fluorescent unit) value at the end-point condition was measured. A reaction profile of fluorometric polymerase activity assay was plotted with $\mathrm{X}$-axis as time in minutes and $\mathrm{Y}$-axis as fluorescence reading. Then, the slope of the curve was determined, and it represented the initial rate of fluorescence change (fluorescence unit/ minutes). The specific activity of the sample was estimated by comparing the initial rate of fluorescence change of recombinant protein with the reaction curve of the standard commercial Taq DNA polymerase (Platinum Taq DNA polymerase, Invitrogen). When the DNA polymerase is active, the primer is extended to form a double-stranded product that binds the EvaGreen dye, with the resulting increase in fluorescence. The rate of increase shows a positive correlation with the polymerase activity (Tveit and Kristensen, 2001).

\section{Application in PCR}

The target gene used as DNA template for PCR amplification was SRV-2 provirus gene (Saepuloh et al., 2009). The $25 \mu \mathrm{L}$ PCR reaction mixture (PCR mix) contained $1 \mu \mathrm{L}$ primary $\mathrm{F}$ and $\mathrm{R}$ with $10 \mathrm{pmol} / \mu \mathrm{L}$ on each primer, $5 \mu \mathrm{L} 5 \mathrm{x}$ PCR buffer (200 mM Tris $\mathrm{HCl}$ pH 8.8, $100 \mathrm{mM}(\mathrm{NH} 4)_{2} \mathrm{SO}_{4}$, $100 \mathrm{mM} \mathrm{KCl}, 20 \mathrm{mM} \mathrm{MgSO}_{4}, 1 \mathrm{mg} / \mathrm{ml} \mathrm{BSA}, 1 \%$ Triton-X), $1 \mu \mathrm{L} 10 \mathrm{mM}$ dNTPs, $2 \mu \mathrm{L} 50 \mathrm{mM}$ $\mathrm{MgCl}_{2}, 1 \mu \mathrm{L}$ Taq DNA polymerase enzyme recombinant, $12 \mu \mathrm{L} \mathrm{dH_{2 }}$ O free nuclease, and $2 \mu \mathrm{L}$ DNA SRV-2/A549 as template DNA. As a control, we used the commercial Taq DNA polymerase enzyme (Platinum Taq DNA polymerase, Invitrogen). The PCR amplification was conducted in the PCR machine (Veriti thermal cycler, Applied Biosystems, USA) with pre-denaturation at $94^{\circ} \mathrm{C}$ for 3 minutes, denaturation at $94^{\circ} \mathrm{C}$ for 30 seconds, annealing at $55^{\circ} \mathrm{C}$ for 30 seconds, and extension at $72^{\circ} \mathrm{C}$ for 2 minutes. This process was repeated 35 cycles and ended with the post-PCR process at $72^{\circ} \mathrm{C}$ for 7 minutes. The PCR amplification product was observed on $1 \%$ agarose gel using the Sybr safe in TAE $1 \mathrm{x}$ buffer at 100 volts for 45 minutes and visualized using Geldoc machine (Biorad). 
The sensitivity test was performed by serial dilution of the provirus SRV-2 DNA template at the concentrations from $100 \mu \mathrm{g} / \mu \mathrm{L}$ to $1 \mathrm{ng} / \mu \mathrm{L}$ using DNA SRV-2/A549 as template DNA and Env 5737 as a forward primer and -5943 as a reverse primer. Meanwhile, the processivity assay was performed to analyze the ability of Taq DNA polymerase recombinant to amplify the target gene at : 206 bp, 506 bp, 1971 bp, 2501 bp to 3531 bp (Table 1).

Table 1. Primers sequences for processivity assay.

\begin{tabular}{llc}
\hline \multicolumn{1}{c}{ Primer names } & \multicolumn{1}{c}{ Sequences } & Amplicons (bp) \\
\hline SRV1/3 5737 U19 (Forward) & 5'-CCAGATGGCTACCAGAACGAY-3' & \\
SRV-2 5943L (Reverse) & 5' AGGGCTTACCGTGTTGTTG-3' & 206 \\
SRV-2 6243L (Reverse) & 5'-CAAAACTGTGGGGACATTGCTA-3' & 506 \\
SRV-2 7708R (Reverse) & 5' GAAACTGCGCCTGTCT-3' & 1971 \\
SeRV 441F (Forward) & 5' GCCGACAGTTAAAGTGAAAG-3' & \\
SeRV 2942R (Reverse) & 5' TGCTT'TGTCCAAT'TCCTCTT-3' & 2501 \\
SeRV 3972R (Reverse) & 5' TCTACGGATAGTTGCTTTTTGA-3' & 3531 \\
\hline
\end{tabular}

\section{RESULTS AND DISCUSSION}

\section{Gene construction}

The total of 2685 bp nucleotides sequences the Thermus aquaticus DNA polymerase gene obtained from GenBank (J04639.1) was used as a reference for the Taq DNA polymerase synthetic gene template. This codon was optimized to obtain the optimum gene expression level in heterologous expression system. Codon optimization is used to avoid the effect of codon bias, which refers to the fact that the frequency of codons usage that encodes certain amino acids varies in different organisms (Brown, 2002). Therefore, this codon optimization correlates with the gene expression level.

Based on GeneOptimizer (GeneArt, USA) bioinformatic program the nucleotides sequences obtained a codon adaptation index (CAI) value of 0.98 , which indicated that the codon usage was well adapted to the bias of E. coli as the host expression system. This optimized gene should therefore allow high and stable expression rate in this expression system. CAI measures the similarity between the codon usage of a gene and the codon usage of a reference group of genes (Sharpl and $\mathrm{Li}, 1987)$. Its values range from 0 (when the codon usage of a sequence and that of the reference set are very different) to 1 (when both codon usages are the same). This index is the most effective of all codon bias measures for predicting gene expression levels (Henry et al., 2007; Puigbò et al., 2007).
Nucleotide sequences before and after codon optimized were aligned using the Clustal Omega (https://www.ebi.ac.uk) and resulted in the identity matrix value of $72.18 \%$. This means that there was $27.82 \%$ nucleotide difference between the native Taq DNA polymerase sequences and the optimized one. The percentage value of the identity matrix refers to the quantitative similarity measurement between two DNA sequences, amino acids, or other (Quick and Sikela 2020). The optimized nucleotides were translated into amino acids using the blastx program (https://blast.ncbi.nlm.nih.gov/Blast.cgi) and produced 894 amino acids encoding Taq DNA polymerase enzyme.

The codon optimized Taq DNA polymerase sequences was synthesized and inserted into the pET151/D-TOPO expression vector. The vector contained $\mathrm{T} 7$ promoters and several other insertion genes, such as polyhistidine coding genes (6xHis), TEV recognition site, and V5 epitope at $\mathrm{N}$-terminal position. The open reading frame (ORF) area encoding the Taq DNA polymerase recombinant enzyme at the nucleotide position of $396 \mathrm{bp}$ until $3080 \mathrm{bp}$ was in frame with initial ATG of the vector. The total of $2685 \mathrm{bp}$ nucleotides containing UAA stop codon were inserted to the sequences due to the $\mathrm{N}$-terminal position of the vector.

\section{Protein expression}

The Taq DNA polymerase synthetic gene in pET151/D-TOPO vector has been successfully expressed in E. coli BL21 (DE3). This strain has 
specially designed for heterologous gene using a T7 promoter and has lysogen lambda DE3 which carries the T7 RNA polymerase gene under the control of the LacUV5 promoter. Analysis of Taq DNA polymerase recombinant protein expression using the SDS PAGE technique showed a $100 \mathrm{kDa}$ specific protein band (Figure 1). This result was in accordance with the protein molecular weight calculation using Compute/Mw program (web.expasy.org) which resulted in 100.9 $\mathrm{kDa}$.

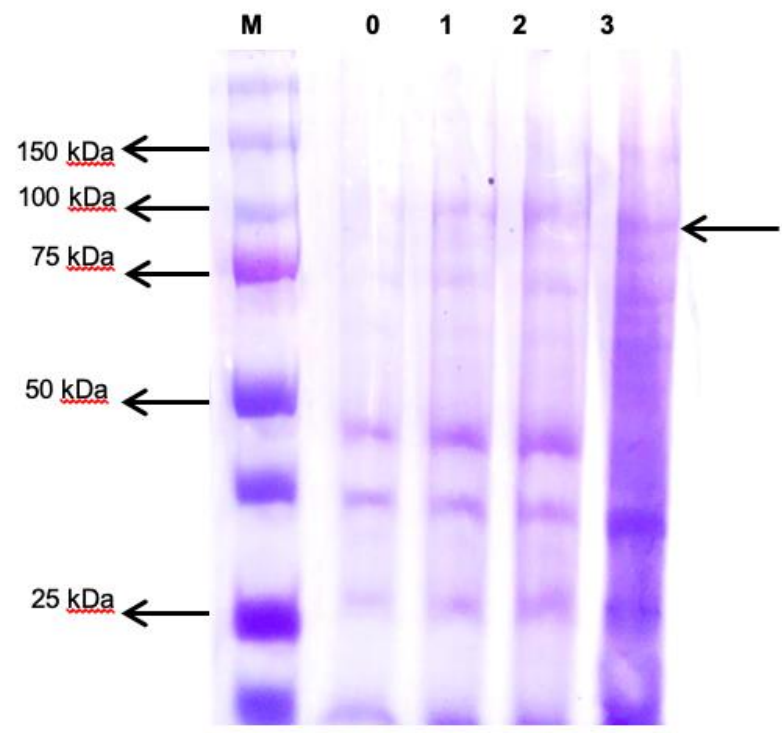

The protein expression level of recombinant Taq DNA polymerase enzyme was induced using IPTG through activation of T7 RNA polymerase related gene (Pluthero, 1993). The SDS PAGE analysis indicated that IPTG enhances the expression of Taq DNA polymerase recombinant proteins that is qualitatively observed from the intensity of the bands (Figure 1). The optimum expression is obtained after the induction with IPTG for 3 hours. The optimization of induction time length had a substantial effect on the protein recombinant yield. Addition of IPTG induces the lacUV5 promoter to produce T7 RNA polymerase, which in turn initiates high-level expression of the target gene in the plasmid (Studier and Moffattf, 1986).

The coding sequence of the T7 RNA polymerase is inserted into the bacterial chromosome under the control of the inducible lac UV5 operon and is transcribed by the endogenous E. coli polymerase. The lac repressor protein (LacI) regulates access to the T7 RNA polymerase coding sequence by binding to the lac UV5 operon. Protein expression induction is triggered by the addition of the inducer such as IPTG, which is a structural non-metabolizable
Protein target $100 \mathrm{kDa}$

Figure 1. Taq DNA polymerase recombinant protein expression observed by Coomassie blue staining shown with $100 \mathrm{kDa}$ protein target band. The level of protein expression after IPTG induction is indicated by the intensity of the band. $\mathrm{M}$ : broad range protein marker, $0-3$ : hours of induction.

analogue of allolactose. The T7 RNA polymerase produced after induction specifically transcribes the coding sequence of the protein of interest that is inserted into the expression plasmid under the control of the T7 promotor (Studier and Moffattf, 1986; Studier et al., 1990).

\section{$\mathrm{Ni}^{2+}-\mathrm{NTA}$ affinity chromatography enzyme purification}

In this study, Taq recombinant DNA polymerase protein was produced in soluble protein and did not form an inclusion body. Therefore, the cells could be lysed in native condition with native buffer without being denatured. This condition is useful to maintain enzyme activity, biological substances, and simplifies the protein purification process. The recombinant Taq DNA polymerase enzyme was purified using the immobilized metal affinity chromatography technique containing $\mathrm{Ni}^{2+}$-NTA (Nickel-Nitrilotriacetate) resin to eliminate non-specific proteins. This resin was used to bind the polyhistidine polypeptide (6xHis) encoded by the 6xHis gene in the pET151/DTOPO vector. The elution was performed using a buffer system containing imidazole at $250 \mathrm{mM}$. Imidazole will compete with $6 \times$ Histag to bind the 
resin containing $\mathrm{Ni}^{2+}$ metal ion resulting in the eluates as purified recombinant Taq DNA polymerase enzyme. This purification results were analyzed using the SDS PAGE technique which showed a $100.9 \mathrm{kDa}$ band in the elution fraction.
This purification technique had successfully minimized the nonspecific proteins target and resulted in $5.17 \mathrm{mg} / \mathrm{mL}$ of the purified recombinant Taq DNA polymerase enzyme (Figure 2).

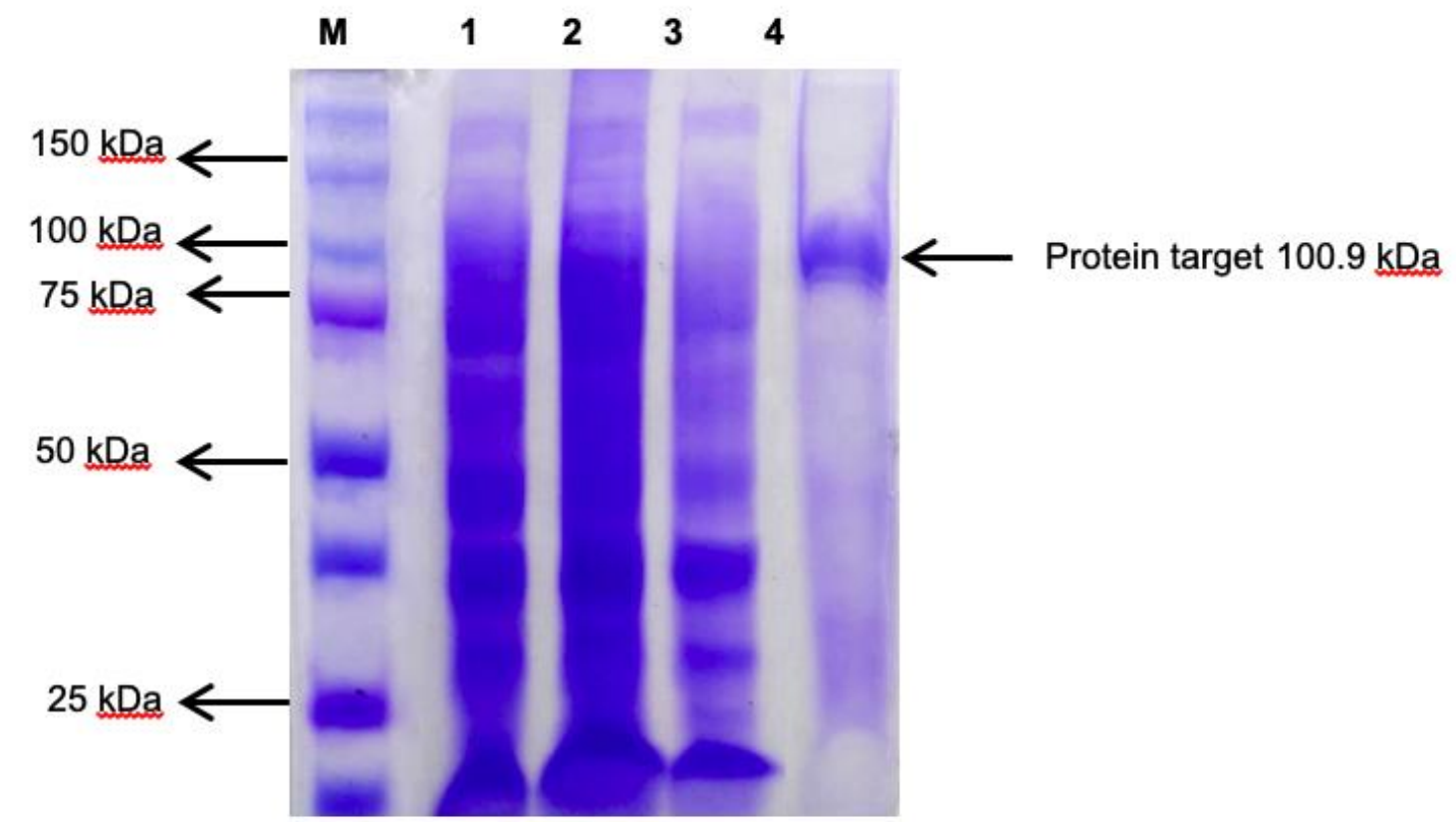

Figure 2. Analysis of $\mathrm{Ni}^{2+}$-NTA affinity chromatography to the Taq DNA polimerase recombinant enzyme using SDS-PAGE with Coommassie blue staining technique. M: broad range protein marker; Lane 1 : crude extract, Lane 2 : flow through of the lysate after binding to resin fraction, Lane 3 : washing with $20 \mathrm{mM}$ imidazole and Lane 4 : elution fraction which was indicated with $100.9 \mathrm{kDa}$ specific protein targets.

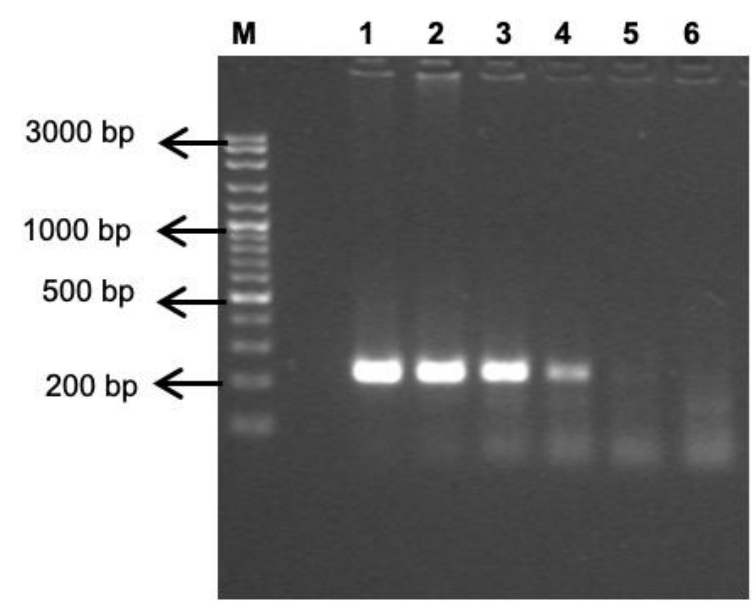

(a)

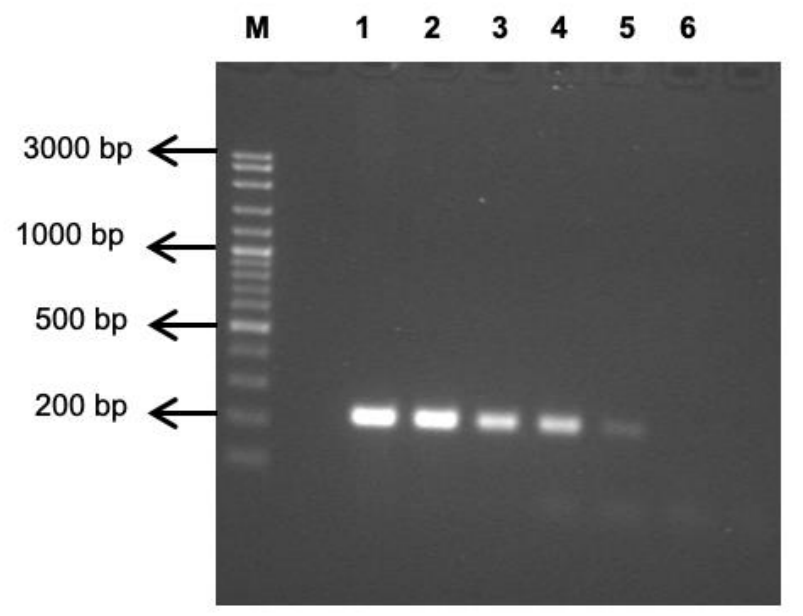

(b)

Figure 3. Enzyme sensitivity measurement of purified Taq DNA polymerase recombinant against the target DNA using various concentrations of template (3a) compared with the commercial Taq DNA polymerase enzyme (3b). Lane $\mathrm{M}=100 \mathrm{bp}$ DNA marker; Lane $1=100 \mu \mathrm{g} / \mu \mathrm{L}$; Lane $2=10 \mu \mathrm{g} / \mu \mathrm{L}$; Lane $3=1 \mu \mathrm{g} / \mu \mathrm{L}$; Lane $4=100 \mathrm{ng} / \mu \mathrm{L}$; Lane $5=10 \mathrm{ng} / \mu \mathrm{L}$ and Lane $6=1 \mathrm{ng} / \mu \mathrm{L}$. 


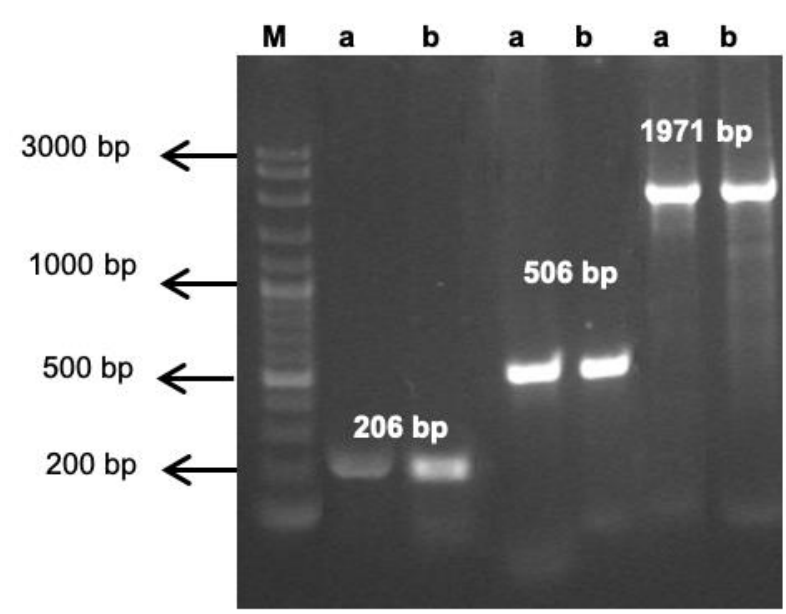

4a

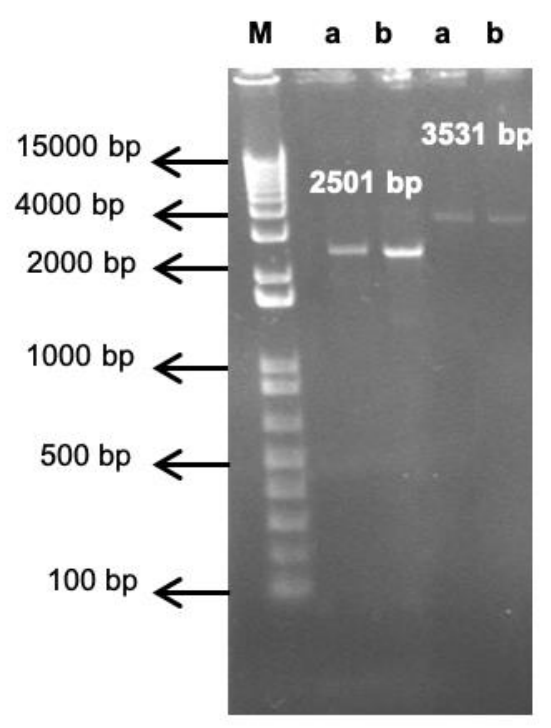

$4 \mathrm{~b}$

Figure 4. Processivity measurement of purified Taq DNA polymerase recombinant enzyme $(1 \mathrm{uL}$ each reaction or 4.647 unit ) (a) to amplify a variety of provirus SRV-2 target gene size compared with commercial Taq DNA polymerase enzyme (b) long sized amplified gene target.

\section{Application of Taq DNA polymerase recombinant enzyme}

The PCR technique was applied to the purified recombinant Taq DNA polymerase enzyme to determine the enzyme activity in the amplified target gene. In this research, the enzyme activity was measured based on the commercial Taq DNA polymerase with known activity enzyme unit. The polymerase enzyme activity unit was 4.647 unit/ $\mu \mathrm{L}$ obtained from the measurements based on the relative fluorescent units (RFU) at the endpoint conditions.

In this research, we also measured sensitivity and processivity of purified recombinant Taq DNA polymerase. The sensitivity assay was performed to determine the minimum concentration of the DNA template that could be amplified by this Taq DNA polymerase recombinant. The sensitivity of this Taq DNA polymerase recombinant was $10 \mathrm{ng} / \mu \mathrm{L}$ DNA concentration that could be amplified using primer Env 5737 5943 SRV-2 provirus target gene that resulted in 206 bp amplicon. This sensitivity assay was also compared to the commercial Taq DNA polymerase as a reference (Figure 3).

The processitivity assay proved the efficacy of the polymerase to synthesize the target gene according to the DNA template. This assay was measured to assess the amplification range of target genes at the same DNA template concentration, in this case $100 \mu \mathrm{g} / \mu \mathrm{L}$. Our purified Taq DNA polymerase enzyme successfully amplified the variety of SRV-2 provirus genes targets at the amplicons $206 \mathrm{bp}$, 506 bp, 1971 bp, 2778 bp until 3531 bp and compared with commercial Taq DNA polymerase enzyme (Figure 4).

According to sensitivity and processivity results of this purified Taq DNA polymerase recombinant enzyme, it is indicated that this enzyme was possible to be applied to the PCR technique extensively on various gene targets. The availability of this in house Taq DNA polymerase recombinant enzyme has been expected to be applied in the molecular biology research, especially in the PCR or RT-PCR technique.

\section{CONCLUSION}

The optimized codon of 2685 bp Taq DNA polymerase synthetic gene cloned in pET151/DTOPO vector was successfully expressed in E. coli 
BL21 (DE3). The SDS-PAGE analysis of Taq DNA polymerase gene expression result was demonstrated by the presence of a specific protein band at $100.9 \mathrm{kDa}$. The $\mathrm{Ni}^{2+}$-NTA purification technique successfully minimized the non-target proteins and resulted in $5.17 \mathrm{mg} / \mathrm{mL}$ purified protein. The application of this enzyme in the PCR technique indicated that, the recombinant enzyme could amplify the various target genes of provirus SRV-2 at $10 \mu \mathrm{g} / \mu \mathrm{L}$ minimum concentration with a variety of amplicons ranging from $200 \mathrm{bp}-3500 \mathrm{bp}$ in size. In general, this preliminary study has successfully developed a Taq DNA polymerase recombinant enzyme using optimized synthetic codon.

\section{ACKNOWLEDGEMENTS}

This research was supported by Primate Research Center (PSSP), IPB University and was conducted in Laboratorium of Biotechnology at Primate Research Center (PSSP), IPB University

\section{REFERENCES}

Brown, T. A. 2002. Genomes. 2nd ed. Oxford: Wiley-Liss.

Chien, A., David, B. E., \& Trela, J. M. 1976. Deoxyribonucleic acid polymerase from the extreme thermophile Thermus aquaticus. Journal of Bacteriology 127(3): 1550-1557.

Engelke, D. R., Krikos, A., Bruck, M. E., \& Ginsburg, D. 1990. Purification of Thermus aquaticus DNA polymerase e xpressed in Escherichia coli. Analytical Biochemistry 191: 396 400.

Gordeeva, T. L., Borschevskaya, L. N., \& Sineoky, S. P. 2010. Improved PCR-based gene synthesis method and its application to the Citrobacter freundii phytase gene codon modification. Journal of Microbiological Methods 81: 147-152.

Henry, I., Sharp, P. M., Sheffield, E. R. S. 2007. Predicting gene expression level from codon usage bias. Molecular Biology and Evolution 24(1): 10-12.

Ishino, S. \& Ishino, Y. 2014. DNA polymerases as useful reagents for biotechnology - The history of developmental research in the field. Frontiers in Microbiology 5(465): 1-9.

Lawyer, F. C., Stoffel, S., Saiki, R. K., Myambo, K., Drummond, R., \& Gelfand D. H. 1989. Isolation, characterization, and expression in Escherichia coli of the DNA polymerase gene from Thermus aquaticus. Journal of Biological Chemistry 264(11): 6427-6437.

Mullis, K. \& Faloona, F. 1987. Specific synthesis of DNA in vitro via a polymerase-catalyzed chain reaction. Methods in Ensymology 155: 335-350.

Niimi, H., Mori, M., Tabata, H., Minami, H., Ueno, T., Hayashi, S., \& Kitajima, I. 2011. A novel eukaryote-made thermostable DNA polymerase which is free from bacterial DNA contamination. Journal of Clinical Microbiology 49(9): 3316-
3320.

Pinheiro, V. B., Taylor, A. I., Cozens, C., Abramov, M., Zhang, S., Chaput, J. C., Wengel, J., Marleen, R., Peak Chew, S. Y., McLaughin, S. H., et al. 2012. Synthetic genetic polymers capable of heredity and evolution. Science 336(6079): 341344.

Pluthero, F. G. 1993. Rapid purification of high-activity Taq DNA polymerase. Nucleic Acids Research 21(20): 4850-4851.

Puigbò, P., Guzmán, E., Romeu, A., \& Garcia-Vallvé, S. 2007. OPTIMIZER: A web server for optimizing the codon usage of DNA sequences. Nucleic Acids Research 35: 126131.

Quick, V. S. \& Sikela, J. 2020. Percent identity of genomic DNA and amino acid sequences. Center for Academic Research and Training in Anthropogeny: 3-5. https://carta.anthropogeny. org $/ \mathrm{moca} /$ topics/percent-identity-genomic-dna-andamino-acid-sequences.

Saepuloh, U., Iskandriati, D., Sadikin, M., \& Pamungkas, J. 2009. Expression of simian retrovirus type D serotype 2 envelope in insect cell using baculovirus expression vector system. Microbiology Indonesia 3(2): 91-95.

Sharpl, P. M. \& Li, W. 1987. The codon adaptation index - a measure of directional synonymous codon usage bias, and its potential applications. Nucleic Acids Research 15(3): 12811295.

Studier, F. W. \& Moffattf, B. A. 1986. Use of bacteriophage T7 RNA polymerase to direct selective high-level expression of cloned genes. Journal of Molecular Biology 189: 113-130.

Studier, F. W., Rosenberg, A. H., \& Dubendorff, J. W. 1990. Use of T7 RNA polymerase to direct expression of cloned genes. Methods in Ensymology 185: 60-89.

Suppan, M., Shamsuddin, S., Ismail, A., \& Balakrishnan, V. 2015. PCR-based gene synthesis, cloning, expression, purification and characterization of Bst DNA polymerase in E. coli cells. Current Synthetic and Systems Biology 3(3): 1-6.

Tveit, H. \& Kristensen, T. 2001. Fluorescence-based DNA polymerase assay. Analytical Biochemestry 298: 96-98.

Wang, Y., Prosen, D. E., Mei, L., Sullivan, J. C., Finney, M., \& Vander Horn, P. B. 2004. A novel strategy to engineer DNA polymerases for enhanced processivity and improved performance in vitro. Nucleic Acids Research 32(3): 1197-1207. 